\title{
The Digital/Technological Connection with COVID-19: An Unprecedented Challenge in University Teaching
}

\author{
Silvia Nuere ${ }^{1}$ (D) $\cdot$ Laura de Miguel $^{2}$ (D)
}

Published online: 6 July 2020

(c) Springer Nature B.V. 2020

\begin{abstract}
In March 2020, due to the COVID19 virus that is spreading throughout the world, Spain lives an anomalous situation concerning the normal course of basic, secondary, and higher education. On March 2nd, 2020, the state authorities announced the end of face-to-face teaching in schools and universities. Then nothing suggests that a week later all classes went canceled. However, this unusual fact does not end with the teaching-learning process, forcing all educational institutions, as well as the teaching community to reinvent themselves to continue with online teaching. This is the only possible way to do it. The authors must face a specific scenario to readapt the learning-teaching process. The way of teaching of the University of La Rioja is online but it will have to face some problems. The Polytechnic University of Madrid classroom education is compulsory, so there is a big gap between what teachers are used to and what they will have to face. This crisis makes us reflect on new technologies as necessary and essential tools in the new teaching-learning scenario presented. But it must also go beyond considering only the tools available to do it. Reflection must also consider the members of this process and those who eventually make possible education to take place.
\end{abstract}

Keywords Online learning · Teaching technologies $\cdot$ Information and communication technology $(\mathrm{ICT}) \cdot \mathrm{COVID} 19 \cdot$ Artistic drawing

\section{Introduction}

The case we are going to analyze contains two scenarios, a distance learning university such as UNIR and another, UPM, where all teaching is based on face-to-face classroom. Both universities offer bachelor's degrees, as well as master's and Doctorate studies. There are several subjects suiting the different degrees, including realizing Final Degree Work, Final Masterwork, as well as internships in companies.

Silvia Nuere

silvia.nuere@upm.es

Laura de Miguel

laura.demiguel@unir.net

1 Universidad Politécnica de Madrid, Madrid, Spain

2 Universidad Internacional de La Rioja, Logroño, Spain 
The University of La Rioja (UNIR), whose headquarters is in La Rioja, was born in 2009 and since the beginning has been a university that has focused on online teaching. This university is a private, familiar with the new communication tools and therefore with applications that ease the teaching-learning process. It has students from different countries around the world. According to a study, in 2018, UNIR continues to keep its leadership against Spanish online universities (Proeduca 2019). At UNIR different degrees with different characteristics are taught: Design, Law, Engineering, and Education between others.

Meanwhile, the Polytechnic University of Madrid (UPM) emerged in 1971 by the union of different centenary schools that were founded between the eighteenth and nineteenth centuries. Each school remained independent until they merge into a single university. It is a public University and in all its Schools teaching is done in classrooms. Being a polytechnic university, the degrees offered are engineering with different specializations. We will focus on the bachelor's degree in Engineering in Industrial Design and Product Development, which has a differentiating factor compared to the rest, by having clearly creative subjects, as for example Artistic Drawing.

Due to the crisis caused by the corona virus COVID19, these two universities have to take measures to avoid contact between their employees, staff of administration and services, teachers and students. Principals of both universities send communications with the appropriate procedure as soon as it comes out. This article will briefly analyze the solutions taken to adapt teaching to the current situation as well as a reflection on the agents of this scenario.

This paper is presented as follows. State of art describes the situation of two universities of Spain under the State of alarm declared under COVID19 crisis. Online learning reviews the framework where action will take part. ICT will revise the technological tools available for the purpose to continue teaching under this specific situation. "UNIR and UPM scenarios" assembles evidences around the action considered to face this new challenge. Discussion will show problems arisen to give quality teaching to students due to specific characteristics of the subject taught. Finally, in the conclusion we will sum up all this study, leaving some questions to be answered.

\section{State of Art}

The first State announcement is to the cancel classroom teaching as usual and the legal enforceability to stay-at-home for, at least, from the 11th till the 17th of March. On March 11th, the UPM's Tele-education Cabinet (GATE), reported that "because of the extraordinary expected Moodle's platform traffic increase, teachers are discouraged from scheduling mass exams, group reservations, or others that need big amount of people access". They inform about the possibility of using Skype for Business, with a document as a guide, commenting that it will be expanded. There also offer the possibility of Office 365 Teams and the option of recording classes in the Recording Studio owned by the UPM. But the latter is canceled by forced confinement.

On March 17th, the School of Engineering and Industrial Design (ETSIDI), where the Degree before mentioned is taught, closed definitively and cannot be accessed. Only those who have researches going on can access with the specific authorization of the Director's School. The 18th of March the Director informs of the options available for online teaching and they set an online class for all the teachers on Thursday, March 
19th through the Jitsi Meet platform (https://meet.jit.si/Intro_Teams_ETSIDI) to talk about Teams platform from Windows. Unfortunately, it does not work, and we connect directly through Teams platform with any previous learning. They just give us basic advice about its use.

On March 19th, after 8 days of teaching stoppage, a communication was received from the principal pointing out that due to the Royal Decree 463/2020 of March 14th, face-toface educational activity was suspended. The obligation remains in force but during the suspension period, educational activities will be maintained through distance and "online" modalities whenever possible". This means that teachers have to change their routine and start, by their own means, searching for tools that allow them to be in contact with students.

On March 24th, after 14 days, the UPM informs teachers of the inclusion of other as Skype for Business, Microsoft Teams (Webinar on March 24) and Blackboard Collaborate by Moodle. They also offer the possibility of using Zoom, with a maximum of 100 students in each session and with the only possibility of recording 40 min of class. Another drawback with the latter application is that it is recommendable for a specific browser.

The UNIR situation is similar, different communications are also sent indicating the cancellation of face-to-face teaching. In the case of this university, there are people who, due to the work they carry out, must go to the UNIR offices, so they allow, on March 10th, teleworking like many other companies. This measure will be mandatory from March 13th. On March 17th, students are allowed to delay their homework. Considering that UNIR is an online university it seems that teachers will not have any problem continuing with their current activities. Nevertheless, there is a lot of staff dedicated exclusively to maintain all the technologies that will not be able to work in the specific facilities.

Let us analyze the frame of reference where teaching is going to take place: online learning.

\section{Online Learning}

This new paradigm of virtuality is not presented as something new. Its value lies in the possibility offered by the means to reinterpret, rethink education and its mechanisms. The theories of learning, methods, didactics, communication, must be placed into a virtual space which is presented with all kinds of creation possibilities. A new path to explore appears. We must keep in mind that we will need creativity to face new training challenges arisen from extreme situations (Fig. 1).

According to Sangrà (2002), there are two models on which this new paradigm must be based, such as the educational model and the one related to the way of organizing it. It is important to focus the educational model on the educational needs of the students. As for the organization, it depends on the higher training and on the interest in investing in the technological tools you need to face a good quality. For Sangrà (2002) fundamental factors of the process of teaching are based on the following axes:

- Accessibility: To guarantee access for all people who want to train and do so through as many means as possible. This involves carefully following the evolution of technology.

- Learning model: To work on improving educational models focused on the way of learning. The learning strategies in the scenario of a virtual and global training space are not the same as those used by students from classroom model universities. 
Fig. 1 Visual thinking about factors of the process of teaching. Laura de Miguel

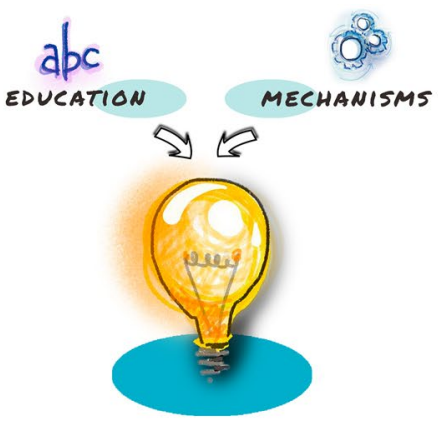

ORGANIZATION MODELS

(TEACHERS AND STUDENTS)

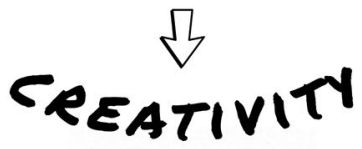

ACCESSIBILITY

ORGANIZATIONALCULTURAL STYLE

LEARNINC MODEL

CROSS-

TEACHING MODELS CULTURAL EXCHANGE

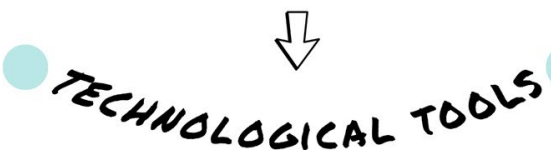

- Teaching models: The profile of teaching professionals should change their goal to facilitate the process of learning instead of instructing. This change must be made from the integration in the shared learning model based on new technologies.

- Organizational-cultural style: One of the great challenges of globalism is to try not to lose the identity, not only cultural, but traditional and historical of the educational organizations. These organizations must keep the prestige they have gained among years. A framework in which there are no own styles of teaching performance is a gray and unattractive space. We will have to work to put the style of our current educational organizations online as well.

- Cross-cultural exchange: The possibility of relating different cultures online is already a working reality. The only problem could be linguistic problems. Not for well-known languages, but for minority languages. 
Among the different theories related to distance education, Sangrà affirms that the student is the essential element in any educational system (2002). The analysis of their specific needs and characteristics are the elements that make condition on the technology to be used in the distance education model to be implemented. The teacher is another fundamental element and, finally, the resources available to make easy the learning model, both based on autonomy or based on communication.

UNIR is constantly evolving with new implementations to improve online teaching. In online education, the use of the latest communication technologies is essential. The educational community in this area can access the virtual campus and launch communications to colleagues and teachers at any time. This is the means of the digital connection is 24hours/7 days a week accessible for all involved people. It is true that this teaching format, favors teacher's family conciliation, avoiding unnecessary travel with the expense of time and money involved. It is also true for students who can combine this type of training with their families, professions or any other personal project they embark on.

However, the UPM has only teaching support tools, such as Moodle platform, but teachers are not prepared for online teaching.

\section{Information and Communication Technology (ICT)}

For Punie, Zinnbauer and Cabrera (2006) there is a widespread belief that ICTs have an important role to play in changing and modernizing educational systems and ways of learning. They consider that ICT can be approached in different ways and that there is no single concept of learning through it.

Models available for distance learning can be synchronous, those in which teaching must be carried out in a real time. Teachers and students coincide, despite not being in the same physical space. They can be asynchronous, where the interaction activity between teachers and students take place at different times and locations (Juárez-Varón et al. 2013). These authors list the technologies available for synchronous teaching:

- Videoconference: a two-way simultaneous audio and video communication process that allows communication between groups of people located in different physical spaces.

- Teleteaching, where only audio and voice exist. Rani and Surana (2015) also include various technologies such as Computer-mediated communication, interactive TV, telephone, software and multimedia network.

- Own television channels.

- Chat services.

As for the asynchronous, we must point out the educational e-learning platforms, teleteaching classrooms that allow recording sessions or classes with an audio and video system. Teachers can also use channels such as YouTube or Vimeo and finally Forums or Blogs (Juárez-Varón et al. 2013).

Obviously, these tools can be accompanied by a guide for the student, a calendar to indicate for example homework deadlines, the possibility of including announcements or specific news. In addition, there are also repositories where the student will find documents related to the subject in addition to the tasks that must be carried out. Finally, there is the possibility, through teleteaching platforms, to carry out exams and subsequently to include the qualifications. 
For both online-based and non-online based universities, e-learning educational platforms are always a support resource for teaching.

To sum up, technological advances in general influence our society and obviously, education cannot be apart from them.

We have already mentioned that in a way or another both universities have some kind of technology to support the teaching-learning process. But let analyze the scenario in each university once the State of Alarm has been set up in Spain.

For years, the so-called online training spaces MOOC (Massive Open Online Course) and OCW (Open Course Ware) have been used by different entities to establish their teaching strategy. In MOOCs, participants get involved as students or as teachers in a massive and freeway, offering a dynamic and participatory experience for both. The OCWs focus on providing content and mechanisms for their public availability (Cormier \& Siemens 2010). These spaces were used quite a few years ago in various professional contexts for permanent professional recycling. Over time, public and private universities have created their own virtual spaces to establish their teaching-learning scenarios. These are virtual spaces that favor the dynamic interaction of teachers and students through their cloud access. For UNIR the interest is focus on the courses done by students when they are doing their internship in companies. Companies offer a specific course to the student and then the university recognize it as European Credit Transfer and Accumulation System (ECTS credits) for their university record. The name of this project is Virtual Mobility Passport (VMPass). They also have the eMundus program, with open learning resources (OER Open Educational Resources). The question is to regulate everything so students can benefit from them (UNIR 2020). For UNIR, MOOCs or OCW do not offer good quality to consider them for recognize them as ECTS.

For the UPM, the university joined the MiriadaX platform to host their MOOCs. A lot of different Spanish institutions have joined this way of spreading culture, as Prado Museum, Telefonica Institute of Technology, Cervantes Institute, or other universities from Spanish based language. UPM just offer different courses, done by their teachers, for different people, no matter if they are students from the university. University students do not benefit from them in their degree record.

\section{UNIR and UPM Scenarios}

What happens then concerning the UNIR? Even though this university is used to manage many essential digital tools that serve the educational community, the presence and work of other nonteaching professionals is needed to ensure the online educational community can develop their work without setbacks. These are the Teaching Organization Technicians (TOT), the Support Technicians (ST), the Class Support Technicians (CST) and the General Administration Personnel (GAP), among others. All of them ensure that the educational community can develop in a normal scenario. Every day, these people carry out their work in specific work centers, offices with a defined schedule and / or shifts to cover a greater time slot to ensure the perfect performance.

In circumstances such as those experienced in the declaration of a national State of Alarm such as the one currently established in Spain by the health emergency authorities of COVID-19, they are deprived of being able to attend these centers. They are force to telework from their homes. For teachers, it is ordinary, as most members of the UNIR educational community, to do it this way. To be able to do this, you must have the 
technological resources that allow remote access to your usual jobs, with the deployment of systems that are necessary in a certain record time. Well, while that is happening the wheel of an online university keeps turning. Classes continue to be taught, students continue to write on their forums, teachers continue to serve them, and so on. Due to the current situation where there are no guarantees of an adequate support, technical problems and needs appear. There is no guarantee to solve them, at least, until the technicians are properly installed in their new workplace, their homes.

These are days, weeks, in which the stability of a given teaching task faces dealing with various fronts beyond its control. They will end assuming that they have front faced it as a superman (Lario 2005) with the idea that things "worked on their own". Suddenly, you become aware that behind the entire virtual network on which you work every day, there is a resource management that, in turn, depends on people. Yes, people. People are the technicians, the students and also the teachers.

Some changes have been done, as for example online meeting instead of face-to-face in the office, but as they have the means, it seems that some days after, everything continues as before the crisis. The internet information traffic of information has increased; the online connections suffer a peak of demand, fact that produces in several occasions' slowdown or even network collapse.

What happens when the university, like UPM, is not ready to teach online? In this case, this situation affects the organization model as Albert Sangrà differentiated. From the first communications in which face-to-face teaching is suspended, there is a period of approximately one week until the university itself begins to send platform options and tools to teach online classes.

As Bonni Stachowiak, columnist for EdSurge (2020), comments, "reading to a webcam instead of an in-person class is not the best way to teach online, but it is the easiest way to switch. Under the circumstances, it is better than nothing. This page was created by teachers, experts and storytellers in 2011 to connect the emerging community of education technology entrepreneurs and educators,

Analyzing the UPM, the scenario is quite difficult. As mentioned before, this university does not have means to teach online, it has only a platform, Moodle which use is not mandatory its use. This is the only Information and Communication Technology (ICT) available for all the community, including emails that the UPM has until then. So, due to the emergency, because of the COVID19 coronavirus, teachers have to use their own means in terms of devices to give their classes. They also must learn from scratch technologies and online software available for this purpose.

Quality may depend on personal equipment needed to teach properly, as well as assuming that students will also be able to easily access any type of teaching tool that is implemented from that moment.

In the end, the teacher becomes the "lone ranger" (Lone Ranger), a concept coined by Bates (2000). He must train from the base; he does not have time to test the tools at his disposal. Furthermore, models called "solitary ranchers" are essential to foster innovation, demonstrate the potential of technology in education, and ensure the use of technology even when there is no systematic support from the institution. Usually, these are teachers who invest much time and effort experimenting with the use of technology in teaching (Bates 2004, p. 40) the quality in the use of new technologies in education requires prior knowledge, not only in content, but with regard to planning, design, and production of the media. 
This crisis should push university institutions to the "technological imperative" named after Bates (2000). They should be updated, not only putting in better tools, but also searching for new tools for subjects with a clearly practical component.

\section{Discussion}

The most important difference between face-to-face and virtuality education lies in the change of medium in the educational potential derived from optimizing the use of each mean. The same cannot be done, but the educational purposes must be the same, and the results must also be the same (Sangrà 2002). The educational system, the rhythm, the evaluation systems must be made more flexible.

In the International University of La Rioja, teachers have continued to teach as always, just some small changes have been done, as online meeting instead of face-to-face ones (Fig. 2). Agility on the system is not always the best, but they manage to continue forward with good results.

The most important changes arise in the Polytechnic University of Madrid, as it is not prepared to online teaching. We are going to expose the challenge lived to teach specific activities to students in a creative subject as Artistic Drawing. It is intended to continue with the teaching requirements, based on the student building their own learning, always from a critical work and acquiring the necessary skills and competencies required for this subject.

In this subject the intention is to learn how to hand sketch so lately they will be able to visually show their design ideas. It is a practical subject with $5 \mathrm{~h}$ a week. Normally the teacher exposes the exercise they have to carry out and they will be drawing and drawing for hours, with personal corrections from the teacher.

For the first week we managed to upload material and videos on the Moodle platform. Nevertheless, "uploading materials online" does not imply online teaching, and it is essential interactivity between student teachers and students with students (Sangrà 2002).

For the theoretical part, the ICT TEAMS tool is suitable, but maybe does not always apply for practical subjects. The first online connection was with $76 \%$ of students. We need

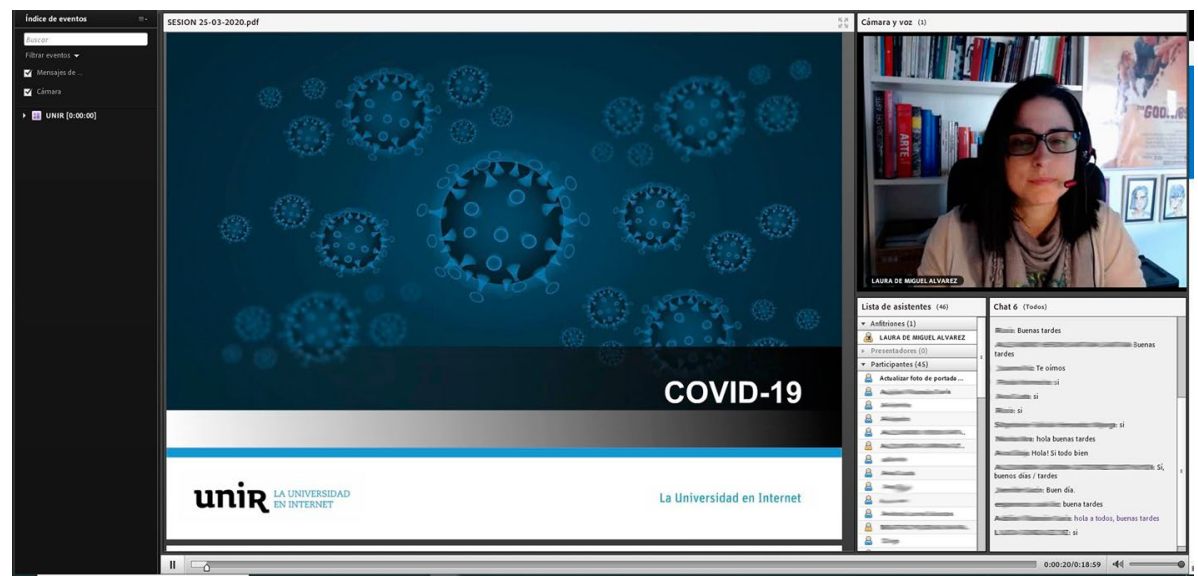

Fig. 2 Teacher having an online meeting with other teachers 
to record online sessions for those who cannot tune life, because as some students choose the subject as optional, maybe they have some time overlap. Even though students can connect their camera so you can see their face, they do not use it. It is right for transmitting information, but you feel alone teaching as you do not even have virtual eye contact (Fig. 3).

For the practical part of the subject, that requires most of the time, the teacher has made a device to be able to connect the camera to show the table so she can draw, and students can see it. This structure was made from PVC pipe, and the piece that holds the camera printed in a 3D printer (Fig. 4). Obviously, all this work has been possible because of the ability of the teacher, and because she had the means to do it.

While speaking, the teacher is drawing explaining visually main points of the topic. Students profit from the teaching drawing, but they need to put it in practice at the same time. This is almost impossible, they can do it, but the teacher cannot see it even if they connect their cameras, because there are almost 40 students at once. Learning artistic drawing is something you need to experience and cannot learn in other hands.

Classes must be taught in their normal schedule and because Spain has two different time zone, students from the Canary Island will have to connect one hour before the others. Also, as they have to upload their drawings and works related to image files, it is a handicap that UPM has limited the capacity from 50 to $20 \mathrm{Mb}$. This forces them to send their homework via email, because visual works are heavy files, so the Moodle platform is not useful anymore.

In other cases, the teacher sends a document to work on. They need to print it to complete their homework, and all at once you are noticed that some of them have not a printer at home. Social network WhatsApp has become a fast way to get in touch with students.

Maybe for assessment we will need to appeal to an e-portfolio as explain by Punie, Zinnbauer and Cabrera (2006):

An e-portfolio or electronic portfolio is a digitalized record of a person's learning achievements including skills, experiences and other achievements. It offers a means of

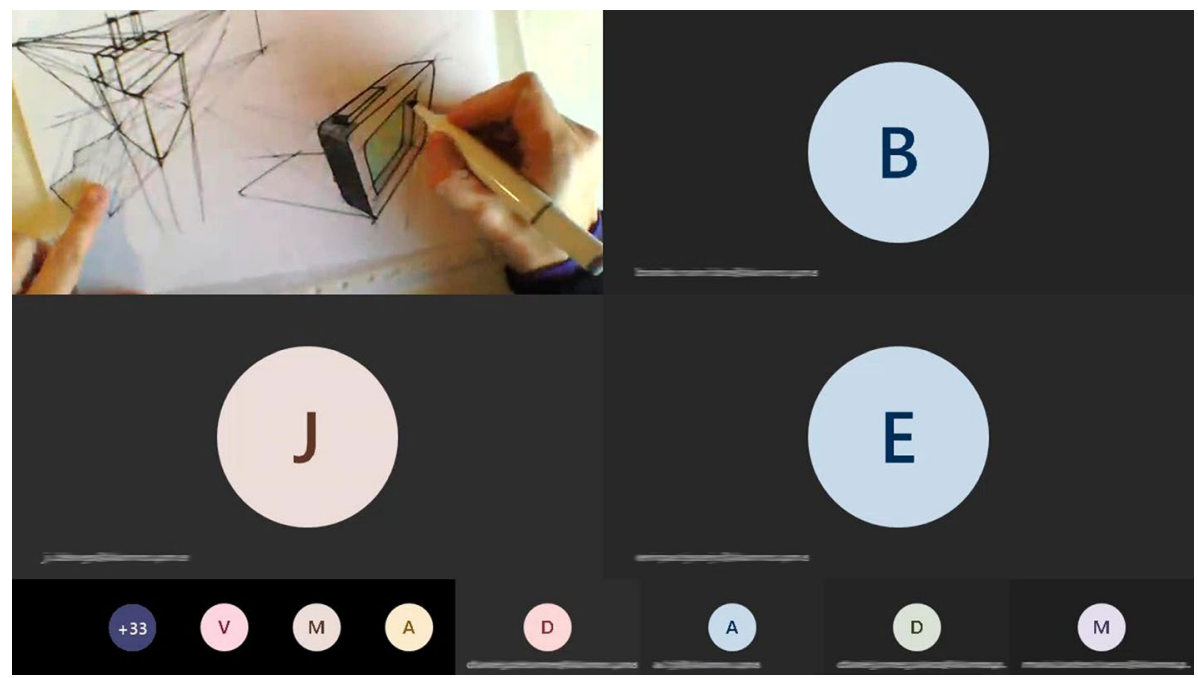

Fig. 3 Teacher having an online class with students 
Fig. 4 a and b Camera support
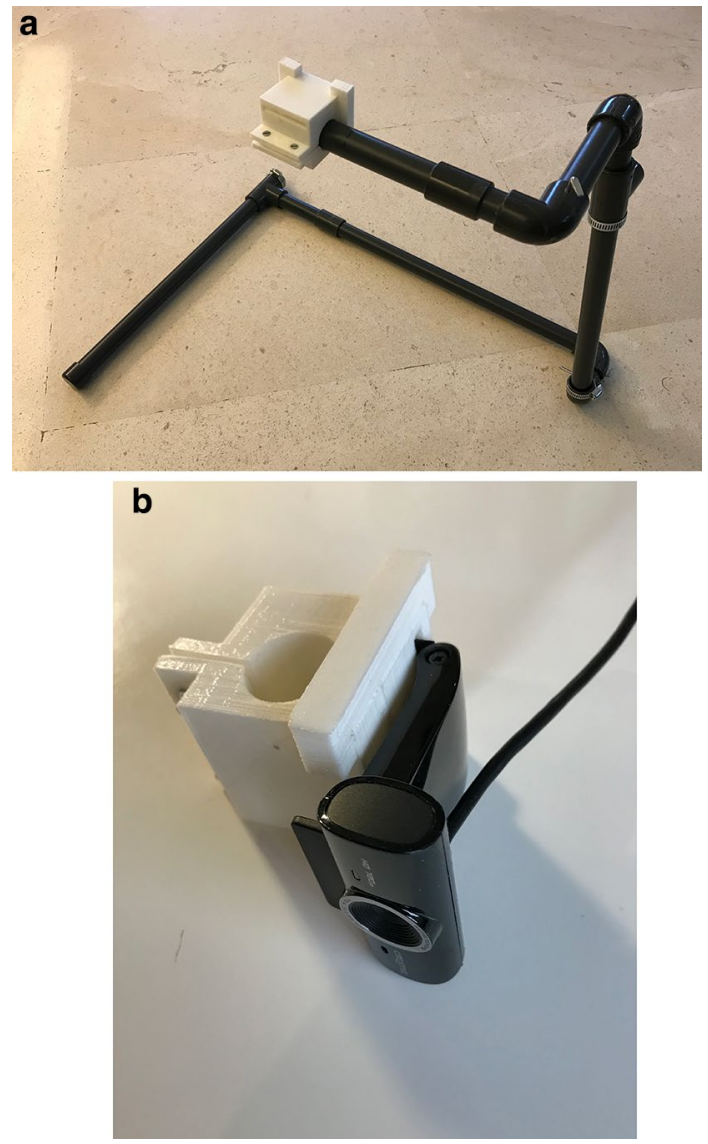

encompassing the full spectrum of student competences in several school subjects and of avoiding assessing only traditional academic competences.

But this is something that we cannot anticipate.

To sum up, if the different steps carried out to teach online are analyzed, the following points can be concluded:

- Universities that are used to online teaching have minimal problems to continue working.

- For the one that does not have good resources to teach online, it is maybe compulsory to think about getting a good online platform for unforeseen circumstances.

- Tools available for the teaching-learning process must be learned by teachers and students in record time.

- Maybe due to the situation, in every house there is only a computer and several members of a family. They maybe have to share the computer as the parents are teleworking, and maybe a brother also needs it.

- The different characteristics that are taught are not considered (artistic drawing, chemistry, physics or electronics laboratories).

- WIFI connections can be weak. 
- For the subject "Artistic Drawing", you realize that previous class work has increased more than double. For example it is not the same telling a student what has to be corrected while they are drawing, than writing one by one (52 students) each personal comment. Also, when you are teaching while drawing on the blackboard, you do it life. For this kind of teaching, you need a specific support to your camera to draw and record everything, at once.

\section{Conclusion}

We have analyzed the different reactions carried out by two universities, one used to teach online and the other with no experience in it. Maybe we can sum up that the use of teaching technologies is essential for an online learning process. Although a University is not prepared for the new technologies of online teaching, should it investigate and invest in tools that facilitate this modality?.

Some problems can also be reflected on Spanish educational budget cuts on public universities. They are not prepared to face such a situation. On the 7th of April, the UPM offered the possibility of borrowing laptops, so teachers could continue with their classes, but this option arrived almost 1 month after confinement. We must also tell that, nowadays, MOOCs or OCW are not a possible solution for UNIR nor UPM online teaching.

Because of the subjects that are difficult to teach within this modality, research should be carried out on suitable technical tools to bring this modality closer to the reality of everyday life in normal times. In these subjects, students have an essential role in the teaching-learning process, and it must be possible a better interaction. Artistic Drawing is a practical subject where students must carry out work from their own experience but based on a theory explained previously by the teacher. This theory can be carried out without problems with the TEAMS tool, but not the personal drawing process. You cannot confirm that the draws they are going to send you lately are made $100 \%$ by them.

And finally, and perhaps most important, the solution lies in the willingness of teachers to innovate without suitable tools. They to keep the wheel turning without losing its rhythm. Teachers, indirect contact with students, report the situation and know that everything will return to normal when technicians are adapted to teleworking. But even though the problem seems controlled because they manage to do it from home, you realize the situation still weird and things go different.

Some teachers and/or technicians become ill, some classes or meetings are suspended until further notice (in the best case) and the wheel keeps turning. This causes that the postponed classes are crowded, and the students are affected by the lack of classes that are not supplemented by other resources. And so on until the situation calms down and an atypical everyday life is rebuilt but normalized by the crisis.

In short, online training, seemingly does not suffer the outcomes of a state of alarm that forces confining its citizens. But being part of those working citizens of mentioned universities who can get sick; this training can be affected by other issues that exceed the border of the walls of a face-to-face university.

As days are passing by, things are getting set up, but differently in each university. UNIR is returning to its normal stage, and even though UPM is giving online classes, this university is still missing some specific aspects of some subjects that cannot be taught that way, as for example artistic drawing, chemistry or electronic laboratories. 
The 30th of March, by the Real Decree 10/2020 from 29th of March, the situation is getting more restrictive from the Spanish government, but online classes continue with our personal technology means. But we still do not know, on the 13th of April, what is going to happen related to the exams if the scenario extends overtime.

Obviously, this paper is two teachers' reflection and the conclusion is that maybe all universities should need a structure to teach online but with good technology at home for every worker to face possible problems. Flexibility is compulsory. Teachers become more than ever the principal actors in the teaching-learning process, readapting their way of teaching. And we do not forget all the people that make necessary that online technology continues to go on and on.

Maybe, after facing such a complicate situation, we realize that people (teachers, technicians, students) are the most important actors. Without their collaboration, even if they have the necessary teaching technology or not, teachers make possible to keep the wheel rolling.

We finish with the quote of an anonymous lighting teacher from the nineteenth century: 'We learn better in contact with people than by their lessons'. We cannot forget that even if we have all means, contact is essential, and those means must ease, if not physical contact, at least eye contact, something difficult with 40,50 or more students. But every subject, as for example artistic drawing, is different and has specific characteristics so maybe, online teaching should take this issue into account in the future. The interaction between teacher while students are drawing is essential.

\section{References}

Bates, T. (2000). Managing technological change. Strategies for college and university leaders. San Francisco: Jossey-Bass.

Bates, T. (2004). La planificación para el uso de las TIC en la enseñanza [Planning for the use of ICT in teaching]. In A. Sangrà, \& M. González Sanmanmed (Eds.), La transformación de las universidades a través de las TIC: discursos y prácticas. [The transformation of universities through ICT: discourses and practices.] Barcelona: Editorial UOC. Accessed March 22, 2020 from https://reader.digitalboo ks.pro/book/preview/28295/00031.html?1585415603663.

Cormier, D., \& Siemens, G. (2010). The open course. Through the open door: Open courses as research, learning, and engagement. Educause Review, 45(4), 30-39.

EdSurge (2020) Coronavirus has led to a rush of online teaching. Here's some advice for newly remote instructors. Accessed March 28, 2020 from https://www.edsurge.com/news/2020-03-11-coronaviru s-has-led-to-a-rush-of-online-teaching-here-s-some-advice-for-newly-remote-instructors.

Juárez-Varón, D., Mengual, A., Vercher, M., \& Peydró, M. A. (2013). Las TIC en la formación online [ICT in online education]. 3 Cienciasvol, 7(1), 1-14.

Lario, S. (2005). Nietzsche, el Superhombre y el Eterno retorno [Nietzsche, the Superman and the Eternal return]. El catoblepas (Vol. 42). Accessed April 24, 2020 from http://nodulo.org/ec/2005/n042p 18.htm.

Proeduca (2019) UNIR se mantiene al frente de las universidades online de España[UNIR remains at the forefront of online universities in Spain]. fAccessed March 23, 2020 from https://www.grupoproeduca. com/noticias-corporativas/prueba-de-noticia-3-de-grupo-proeduca-altus/.

Punie, Y., Zinnbauer, D., \& Cabrera, M. (2006). A review of the impact of ICT on learning. JRC Technical Notes. European Commission: IPTS. Working paper prepared for DG EAC. Accessed March 21, 2020 from ftp://ftp.jrc.es/pub/EURdoc/JRC47246.TN.pdf.

Rani, S., \& Surana, A. (2015). The future of teleteaching in teacher education. The International Journal of Indian Psychology, 3(1), 8.

Rodriguez, Q. (2011). Universidades online: la historia de un sector en ebullición [Online universities: the history of a boiling sector]. Accessed March 23, 2020 from https://www.expansion.com/2011/07/11/ empleo/desarrollo-de-carrera/1310376088.html. 
Sangrà Morer, A. (2002). Educación a distancia, educación presencial y usos de la tecnología: una tríada para el progreso educativo. [Distance education, face-to-face education and uses of technology: A triad for educational progress]. Edutec. Revista Electrónica De Tecnología Educativa, 15, a024. https://doi. org/10.21556/edutec.2002.15.541.

Spanish Royal Decree 463/2020 (2020, march, 14th). Accessed March 15, 2020 from https://www.boe.es/ buscar/act.php?id=BOE-A-2020-3692.

Spanish Royal Decree 10/2020 (2020). Accessed March 31, 2020 from https://www.boe.es/buscar/act. php?id=BOE-A-2020-4196.

UNIR (2020) Los MOOC no son una revolución en el mundo educativo [MOOC are not a revolution for the educational world]. Accessed April 24, 2020 from https://research.unir.net/blog/los-mooc-no-son-unarevolucion-en-el-mundo-educativo/?lang=es.

UPM (2020) Los MOOCs en la UPM [MOOCs in the UPM]. Accessed April 24, 2020 from https://innov acioneducativa.upm.es/mooc.

Publisher's Note Springer Nature remains neutral with regard to jurisdictional claims in published maps and institutional affiliations. 